\title{
Efficiency of pollutant removal in a hybrid constructed wetland with Hedychiumcoronarium J. König: a sustainable alternative for poor communities
}

\author{
Eficiência na remoção de poluentes por sistema alagado híbrido com \\ Hedychiumcoronarium J. König: uma solução para comunidades de \\ baixa renda
}

\section{Brennic Menezes Amaral'id, Douglas Pires Alcântara' ${ }^{(\mathbb{D})}$, Eva de Melo Ferreira' ${ }^{(\mathbb{D})}$, Karla Alcione da Silva Cruvinel'(i) \\ ' Universidade Federal de Goiás. Goiânia, GO, Brazil}

\begin{abstract}
Wastewater treatment in developing countries is a problem of access and efficiency. Individual wastewater treatment systems are important when the sewage collection network does not reach the whole community. Therefore, the treatment efficiency should be evaluated when considering systems design and the prevention of environmental negative impact. Wetland's systems are often used as final treatment for wastewater polishing. This work proposes a wastewater treatment using a hybrid system consisting of septic tank, anaerobic filter, and a wetland system using plants as tertiary treatment. Samples were collected to evaluate biochemical oxygen demand (BOD), chemical oxygen demand (COD), turbidity, apparent colour, total solids, total phosphorus (TP) and nitrogen. In two points analysed the contaminant removal was a result of septic tank set with the anaerobic filter. The efficiency of the system was recognized to improve the quality of the final effluent, showing as an excellent alternative to countries with lack of collective structures for the treatment of domestic sewage.
\end{abstract}

Keywords: Contaminants; Greywater; Sustainability; Sustainable communities; Water reuse

\section{RESUMO}

O tratamento de águas residuárias em países em desenvolvimento é um problema de acesso e eficiência. Os sistemas individuais de tratamento de esgoto são importantes quando a rede de coleta não chega a toda a comunidade. A eficiência do tratamento deve ser avaliada ao considerar o projeto dos sistemas e a prevenção do impacto ambiental negativo. Os sistemas de tratamento de esgoto são frequentemente 
utilizados como tratamento final para o polimento de águas residuárias. Este trabalho propõe um tratamento de esgoto utilizando um sistema híbrido composto de fossa séptica, filtro anaeróbico e um sistema de zonas úmidas utilizando plantas como tratamento terciário. Foram coletadas amostras para avaliar a demanda bioquímica de oxigênio (DBO), demanda química de oxigênio (COD), turbidez, cor aparente, sólidos totais, fósforo total (TP) e nitrogênio. Em dois pontos analisados, a remoção de contaminantes foi resultado do conjunto de fossas sépticas com o filtro anaeróbico. A eficiência do sistema melhorou a qualidade do efluente final, mostrando como uma excelente alternativa aos países com falta de estruturas coletivas para o tratamento de esgoto doméstico.

Palavras-chave: Contaminantes; Águas cinzas; Sustentabilidade; Comunidades sustentáveis; Reuso da água

\section{INTRODUCTION}

Wastewater systems are critical to poor communities. They protect residents from waterborne contamination. Conventional wastewater treatment has contributed substantially to the progress in health and environmental protection (KÜMMERER et al., 2018), but in Brazil it is not available in all the cities, where 36 municipalities in the country's 100 largest cities have less than $60 \%$ of the population with sewage collection (TRATA BRASIL, 2019).

Unfortunately, maintaining enough pollutants removal is not a priority for all governments, being important to remove dirt from the population's field of vision. Wastewater treatment plants (WTPs) have received considerable attention over the past decades because it act as a barrier to prevent micropollutants (MPs) from entering the environment. Intensive sampling and analysis efforts have been made globally to improve understanding of the occurrence, behaviour, and fate of MPs in WTPs (BEN et al., 2018).

In the face of the emerging concern for environmental preservation and governmental regulations that are becoming more stringent the development of innovative, sustainable, environmentally friendly, and low-cost processes for efficient treatment of tannery wastewater has gained the interest of researchers in clean technologies (ASSEFA et al., 2019). The performance of systems for wastewater treatment for the safe release of the effluent (e.g., for the protection of human health and the environment) is the primary role. Research studies have 
evaluated the performance of these systems with respect to their ability to remove potentially harmful constituents (DIAZ-ELSAYED et al., 2017).

One solution for the wastewater treatment in poor communities is the constructed wetlands (CWs). CWs, as an increasingly popular option for wastewater treatment, has been used for over fifty years (XU et al., 2019). CWs comprise a suite of recognized eco-technologies that are designed and constructed to mimic and manipulate the simultaneous physical, chemical, and biological processes occurring in natural wetlands for wastewater treatment purposes.

Besides the water quality improvement, CWs also provide a multitude of other functions, such as biodiversity, habitational, climatic, hydrological, and public use functions (WU et al., 2018). Furthermore, playing an important role in the environmental plan to achieve both federal, state regulatory compliance for effluent discharges (XU et al., 2019), and have been used effectively for the inactivation of bacterial indicators (KALIAKATSOS et al., 2019).

CWs are categorized according to its hydrology to the free water surface (FWS) CWs and the subsurface flow (SSF) CWs. FWS systems are like natural wetlands, with shallow flow of wastewater over-saturated substrate (KALIAKATSOS et al., 2019). For the construction of such systems, it would be economically feasible to use naturally available materials and local vegetation as filler agents. Elimination of pathogenic germs takes place in the filter body and root zone area of CWs, which can exceed the elimination capacity of conventional, biological wastewater treatment plants.

Selection of the substrates and macrophytes is therefore a crucial aspect while designing CWs (SHINGARE et al., 2017). CWs, composed of low-cost materials and ecological plants, serve the simultaneous nitrification, anammox and denitrification process with conducive conditions. The packing substrates and plant surfaces can provide immense interface for the attachment of microorganisms associated to nitrogen cycle (CHEN et al., 2019). 
Considering the importance of CWs technology to developing countries, the main goal of this work is to propose a wastewater treatment using a hybrid system consisting of septic tank, anaerobic filter, and a wetland system using plants as tertiary treatment in Brazil.

\section{MATHERIAL AND METHODS}

A hybrid wastewater system was designed, consisting of a septic tank, anaerobic filter, and CW, with inspection boxes between the system units. The unevenness of the site was used, using gravity for the sewage flow in the system. The sizing has prioritized the use of materials to run an efficient and cost-effective system.

To analyse the economic viability of the system implementation, the budget was initially executed using plastic bottles such as for the septic tank and anaerobic filter and a water tank for the CW (Figure 1), and in second moment using masonry tanks for all units. The volume for the septic tank was $240 \mathrm{~L}$, considering the size of the plastic drums.

Figure 1 - Hybrid constructed wetland used (n. 1-4 is the monitoring points)

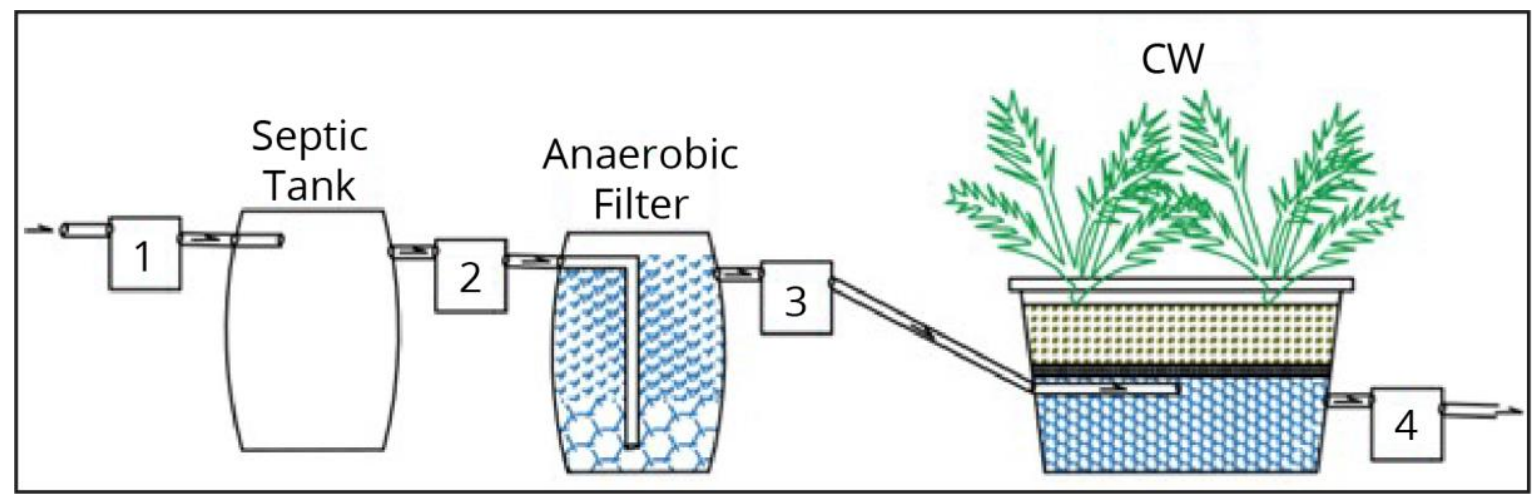

Source: Authors, 2021

The hydraulic detention time was 0.75 days (18 hours), meeting the economic and constructive criteria. Wastewater consisting of soluble materials and with 
considerable suspended solids content may cause problems related to undesirable filling of the bed interstices that may hinder the passage of water.

One of the main problems related to the durability and functionality of anaerobic filters is closely linked to filter bed clogging (CRUZ et al., 2013). To minimize this possible problem and extend the life of the filter, a $40 \mathrm{~cm}$ layer of crushed stone was used at the bottom, with a particle size ranging from $64 \mathrm{~mm}$ to $170 \mathrm{~mm}$, followed by gravel number 4 in the rest (Figure 2).

Figure 2 - Anaerobic filter dimensions (cm)

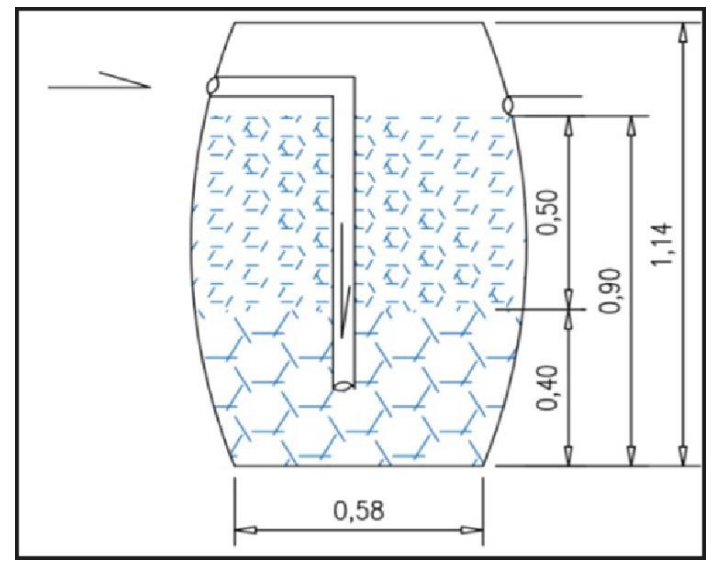

Source: Authors, 2021

Mota and Sperling (2009) indicate the subsurface flow efficient for septic tank effluent treatment besides having a satisfactory landscape structure. The CW was dimensioned following the literature, in which the authors adopted the per capita area ratio as the sole criterion. The relationship varies according to the characteristics of the effluent studied by each author. According to the technical literature, the range of 1 to $5 \mathrm{~m}^{2}$ per person is the most usual (SEZERINO et al., 2004).

The choice of substrate followed the recommendations described in a literature review, which emphasizes that the substrate must have a large contact surface area, function as a filter medium, support medium for the development of microorganisms and root fixing medium (PITALUGA, 2011). A $1000 \mathrm{~L}$ water tank with a $1.82 \mathrm{~m}^{2}$ surface area was used as material for the wetland unit. It was filled 
at the bottom $(40 \mathrm{~cm})$ with gravel n. 4, followed by a $10 \mathrm{~cm}$ layer of sand and ending with $20 \mathrm{~cm}$ of soil, forming the area for fixing the plants. The species Hedychiumcoronarium J. König) was inserted in the project implementation region, meeting the criteria of efficiency and adaptation to the local climate of Brazilian savannah, Figure 3 (ALMEIDA et al., 2007).

Figure 3 - CW's dimension (cm)

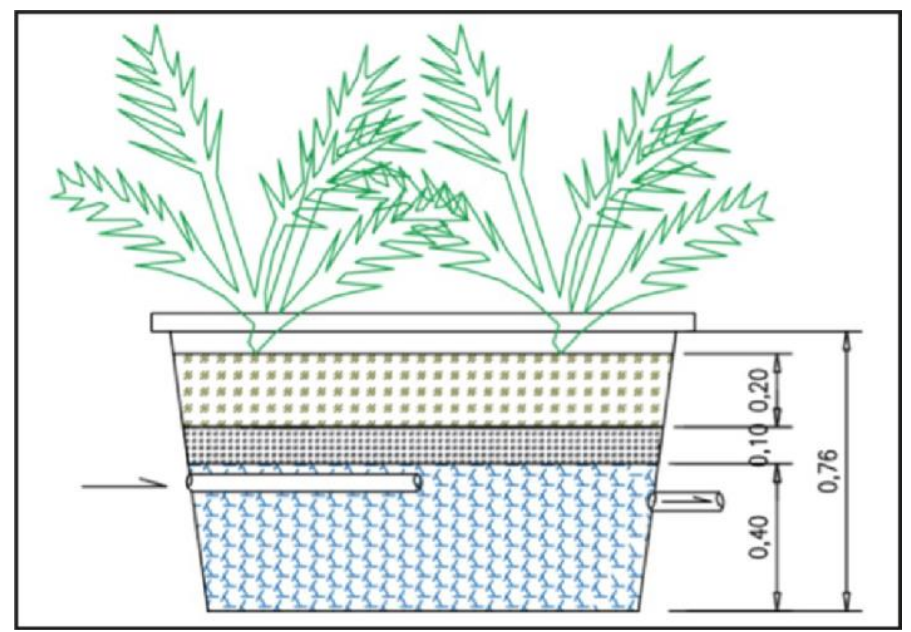

Source: Authors, 2021

Figure 4 - Plants in the first month of transplantation (A) and after three months (B)

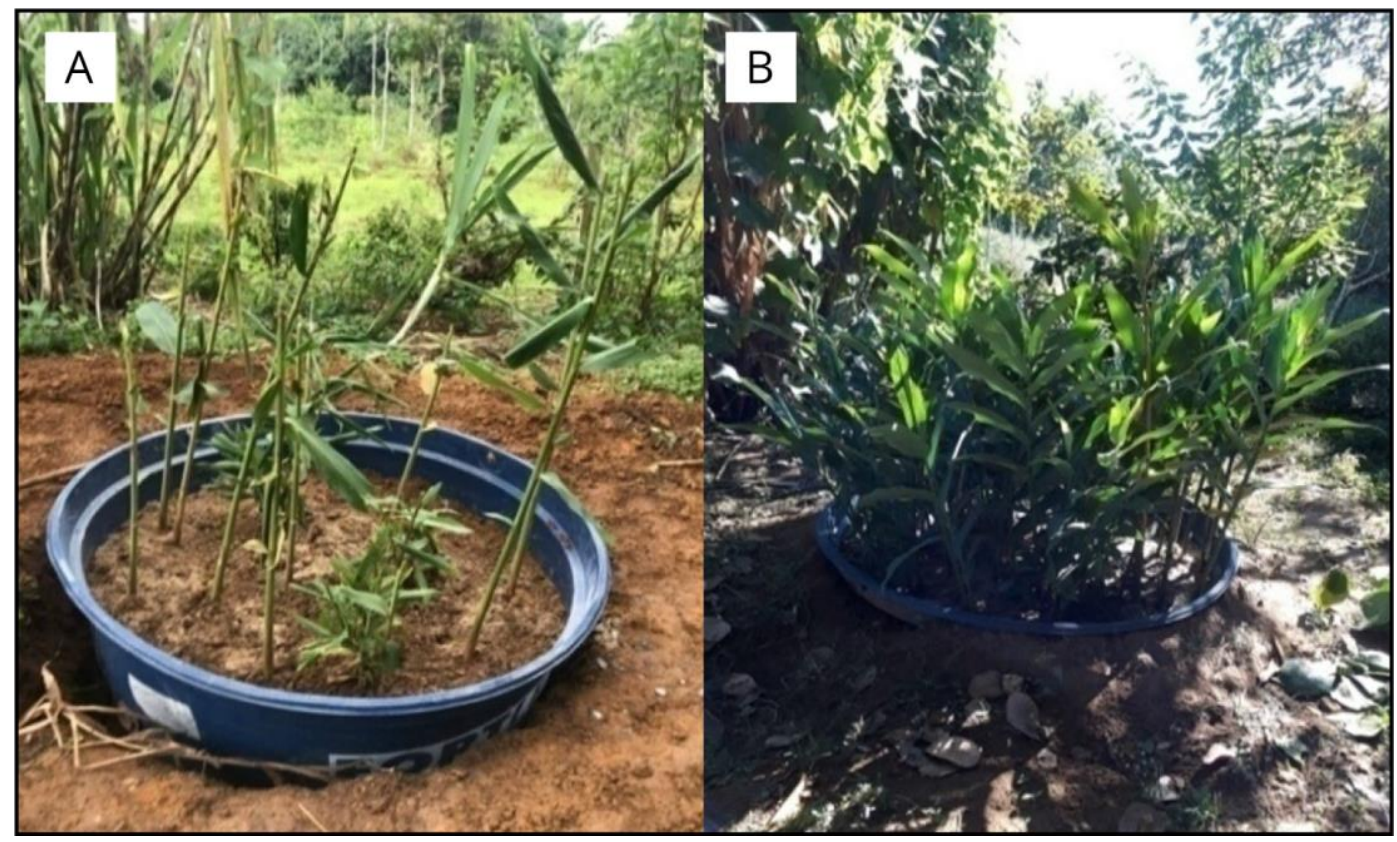

Source: Authors, 2021 
The construction of the system involved the excavation of the holes to accommodate the system, the water box, and the inspection boxes, later the accommodation of the gravel in the filter and as a filter bed of the cultivated bed. The species chosen for the cultivated bed facilitated the consolidation of the system, being found around the construction site and transplanted (Figure 4). The effluent water level remains below the support medium without insect proliferation, controlling odour by isolating the effluent from animals and human contact.

The wastewater samples were made after three weeks of stabilization, in the boxes number one, three and four, representing the non-treated wastewater at the system entrance, the effluent before entering the constructed flooded and the treated effluent. The sampling occurred fortnightly between April, May and June and were subjected to laboratory analysis, according to Standard Methods for the Examination of Water and Wastewater (APA) for BOD, COD, $\mathrm{pH}$, total solids, alkalinity, colour, turbidity, ammonia total nitrogen and phosphorus.

Based on the results, characteristic values of pollution parameters in sewage from the three different treatment stages were determined, including average, minimum and maximum values, and medians. The relative frequency of occurrence of the characteristic concentration levels of the tested parameters in the sewage flowing into the treatment plant was determined (Table 1).

Table 1 - Descriptive statistics for the indicator values in the treated wastewater

\begin{tabular}{|c|c|c|c|c|c|c|c|c|c|}
\hline & $\begin{array}{c}\text { Turbity } \\
\text { (uT) }\end{array}$ & $\begin{array}{l}\text { Colour } \\
\text { (Uc) }\end{array}$ & $\begin{array}{l}\text { Total } \\
\text { solids } \\
\text { (mg/L) }\end{array}$ & $\begin{array}{l}\text { BOD } \\
\text { (mg/L) }\end{array}$ & $\begin{array}{c}\text { COD } \\
(\mathrm{mg} / \mathrm{L})\end{array}$ & $\begin{array}{l}\text { Total P } \\
\text { (mg/L) }\end{array}$ & $\begin{array}{c}\text { Total } \\
\mathrm{N} \\
(\mathrm{mg} / \mathrm{L})\end{array}$ & $\begin{array}{c}\text { Alkalinity } \\
\text { (mg } \\
\text { CaCO3/L) }\end{array}$ & pH \\
\hline \multicolumn{10}{|c|}{ First sampling } \\
\hline S1 & 37 & 7010 & 2160 & 988 & 2958 & 47,5 & 148,4 & 1240 & 7 \\
\hline S2 & 12 & 650 & 417 & 128 & 380 & 12 & 21 & 340 & 7 \\
\hline S3 & 20 & 1311 & 561 & 97 & 440 & 8 & 25 & 486 & 6 \\
\hline $\begin{array}{l}\text { Septic tank } \\
+ \text { filter }\end{array}$ & 67 & 90 & 80 & 87 & 87 & 74 & 85 & & \\
\hline $\mathrm{CW}$ & -65 & 101 & 34 & 24 & 15 & 29 & -15 & & \\
\hline $\begin{array}{l}\text { Total } \\
\text { efficiency }\end{array}$ & 45 & 81 & 74 & 90 & 85 & 82 & 83 & & \\
\hline
\end{tabular}

Note: S1 - before the flow; S2 - after the septic tank; S3 - after the anaerobic filter

Continued... 
Table 1 - Conclusion

\begin{tabular}{|c|c|c|c|c|c|c|c|c|c|}
\hline & $\begin{array}{l}\text { Turbit } \\
\text { y (uT) }\end{array}$ & $\begin{array}{l}\text { Colour } \\
\text { (Uc) }\end{array}$ & $\begin{array}{l}\text { Total } \\
\text { solids } \\
\text { (mg/L) }\end{array}$ & $\begin{array}{c}\text { BOD } \\
(\mathrm{mg} / \mathrm{L})\end{array}$ & $\begin{array}{c}\text { COD } \\
(\mathrm{mg} / \mathrm{L})\end{array}$ & $\begin{array}{l}\text { Total P } \\
\text { (mg/L) }\end{array}$ & $\begin{array}{c}\text { Total } \\
\mathrm{N} \\
(\mathrm{mg} / \mathrm{L})\end{array}$ & $\begin{array}{l}\text { Alkalinity } \\
\text { (mg } \\
\text { CaCO3/L) }\end{array}$ & $\mathrm{pH}$ \\
\hline \multicolumn{10}{|c|}{ Second sampling } \\
\hline S1 & 259 & 4650 & 1760 & 524 & 5840 & 45 & 123 & 886 & 7 \\
\hline S2 & 130 & 1110 & 568 & 144 & 397 & 11 & 61 & 520 & 7 \\
\hline S3 & 102 & 720 & 480 & 53 & 245 & 9 & 50 & 606 & 7 \\
\hline $\begin{array}{l}\text { Septic tank } \\
+ \text { filter }\end{array}$ & 49 & 76 & 67 & 72 & 93 & 75 & 50 & & \\
\hline CW & 21 & 35 & 15 & 63 & 38 & 18 & 18 & & \\
\hline $\begin{array}{l}\text { Total } \\
\text { efficiency }\end{array}$ & 60 & 84 & 72 & 89 & 95 & 80 & 59 & & \\
\hline \multicolumn{10}{|c|}{ Third sampling } \\
\hline S1 & 940 & 6950 & 3253 & 1130 & 2300 & 33 & 85 & 852 & 7 \\
\hline S2 & 267 & 1390 & 576 & 162 & 322 & 6 & 53 & 516 & 6 \\
\hline S3 & 112 & 303 & 605 & 26 & 127 & 6 & 70 & 652 & 7 \\
\hline $\begin{array}{l}\text { Septic tank } \\
+ \text { filter }\end{array}$ & 71 & 80 & 82 & 85 & 86 & 81 & 37 & & \\
\hline CW & 58 & 78 & -5 & 84 & 60 & 3 & -31 & & \\
\hline $\begin{array}{l}\text { Total } \\
\text { efficiency }\end{array}$ & 88 & 95 & 81 & 97 & 94 & 81 & 18 & & \\
\hline \multicolumn{10}{|c|}{ Fourth sampling } \\
\hline S1 & 356 & 5874 & 1002 & 505 & 1165 & 13 & 67 & 865 & 7 \\
\hline S2 & 249 & 1530 & 843 & 351 & 631 & 6 & 65 & 612 & 7 \\
\hline S3 & 61 & 225 & 518 & 74 & 277 & 5 & 50 & 686 & 7 \\
\hline $\begin{array}{l}\text { Septic tank } \\
+ \text { filter }\end{array}$ & 30 & 74 & 15 & 30 & 45 & 50 & 2 & & \\
\hline CW & 75 & 85 & 38 & 78 & 56 & 24 & 23 & & \\
\hline $\begin{array}{l}\text { Total } \\
\text { efficiency }\end{array}$ & 82 & 96 & 48 & 85 & 76 & 62 & 25 & & \\
\hline $\begin{array}{l}\text { Total } \\
\text { efficiency }\end{array}$ & 69 & 89 & 69 & 90 & 87 & 76 & 46 & & \\
\hline
\end{tabular}

Note: S1 - before the flow; S2 - after the septic tank; S3 - after the anaerobic filter

\section{RESULTS AND DISCUSSION}

For evaluation of treatment performance of CWs, current research is mainly focused on the measurement of the rate of removal of pollutants such as total nitrogen TN, TP, ammonium nitrogen $\left(\mathrm{NH}_{4}+-\mathrm{N}\right)$ and on determination of COD. Water depth, plant spacing, and layout of inland outlet are the main factors affecting the efficiency of pollutant removal. These design parameters displayed 
significant influence on hydraulic performance and negligible effect on treatment performance (Guo et al., 2019). In a study which investigated hybrid CWs, the system had organic and biogenic pollutant removal efficiencies like those obtained in systems using classic plant species such as reed and willow (MARZEC et al., 2019).

Plants are essential for the system functioning and are responsible to reduce the velocity of particle flow, which is beneficial to particle dissolution and solute adsorption; transport gas and solutes between plant leaves, stems, and roots; absorb organic pollutants; and release $\mathrm{O}_{2}$ into the rhizosphere. Within wetland systems, plants, coupled with microorganisms, employ physical, chemical, and biological processes to purify polluted water (IJAZ et al., 2015).

In the plant-bacteria association, plants assimilate nitrogen to promote growth and provide ideal attachment sites for microbial communities and regulate bacterial nitrification and denitrification by oxygen and organic compound release in the root zone (PENG et al., 2014; WU et al., 2017). For example, common reed (Phragmites australis), willow (Salix viminalis), giant miscanthus (Miscanthus giganteus), Jerusalem artichoke (Helianthus tuberosus), Virginia mallow (Sida hermaphrodita), Manna grass (Glyceria maxima), and marsh lily (Hedychiumcoronarium J. König) can be used as species (JÓŹWIAKOWSK et al., 2019).

It has been widely recognized that CWs are a reliable treatment technology for various wastewaters after years of study and implementation. The current study indicates that advances in the design and operation of CWs have greatly increased contaminant removal efficiencies (WU et al., 2015). In a study developed for two years, water flow, temperature, $\mathrm{pH} \mathrm{O}^{2}$ and target indicators were monitored over a period of two years, after the first year of vegetation establishment. Different from the research made in Brazil, one control system with aeration was used. At 28 days, there was a reduction in colour in the aerated system combined with vegetation.

No significant effect on colour reduction was obtained for either aeration or vegetation alone. The parameter $\mathrm{pH}$ could affect the colour of the water. However, 
no relationship between colour and $\mathrm{pH}$ was observed in this investigation. This could be because $\mathrm{pH}$ was higher than expected during the monitoring period in all mesocosms (SVENSSON et al., 2015).

In a hybrid system consisted of a serially operated horizontal sub-surface flow constructed wetland (HSSF-CW) and a vertical sub-surface flow constructed wetland (VSSF-CW), operated at five periods each lasting about four months, temperature was one of the factors to influence the system efficiency. The authors explain that temperature should be considered as a determining factor in constructed wetland treatment of domestic wastewaters in terms of the removal of $\mathrm{N}$, for example. Higher temperatures can accelerate the treatment process.

The whole treatment system including anaerobic pre-treatment achieved on average up to more than $95 \%$ organic matter and $90 \%$ nitrogen removal. This resulted in effluent COD concentrations below $20 \mathrm{mg} / \mathrm{L}$ with a specific wetland surface area of only about $1 \mathrm{~m}^{2}$ per person. Comparison of Period I (during summer with an average influent water temperature of $23 \pm 4 \mathrm{C}$ ) and Period II (during winter with an average influent water temperature of $16 \pm 2$ C) showed that removal efficiencies of organic matter (COD and BOD5), total nitrogen (TN) and suspended solids (TSS) were all higher in the summer period compared to the winter period (AYAZ et al 2015).

The ammoniacal nitrogen in the beginning of the system was $143 \mathrm{mg} / \mathrm{L}$, going to $79 \mathrm{mg} / \mathrm{L}$ in the $4^{\text {th }}$ sampling, showing the efficiency of the CW studied. In constructed wetlands, the main processes of nitrogen removal by microorganisms are ammonification, nitrification, and denitrification. Denitrification is a chemical reaction in which denitrifying bacteria reduce the nitrate or nitrite produced in the system. Nitrification occurs under aerobic conditions, while denitrification occurs under hypoxic conditions since denitrifying bacteria are heterotrophic facultative anaerobic microorganisms.

Constructed wetlands can provide both anaerobic and aerobic microenvironments to ensure efficient nitrogen removal (DING et al., 2018). Turbity, total 
solids and BOD increased in the third sampling, at the first point, right after the anaerobic filter. This could be improved by an aeration system but increasing the costs with energy and with the project construction.

Apparent colour may be related to turbidity due to particulate matter. The first sampling shows a reduction in colour and turbidity from point one to point two, and subsequently at point three the values increased. This ascendancy of the colour and turbidity values in point three of analysis one may be justified due to the stabilization process of the system.

Suspended particles were present in the cultivated bed substrate. The system was still being "washed" by the tributary during sample collection for the first sampling. In fourth sampling the result for colour increased from point two to three, requiring further study, since the other parameters analysed in this work did not identify any result that explains such ancestry. The average efficiency in colour removal and turbidity were $89.4 \%$ and $69.3 \%$, respectively.

Turbidity and total solids in the third sampling showed a very high value at first point compared to the other analyses, but at second, the values fell and were closer to the other analyses and may judge that the system is capable of absorb sporadic events of high turbidity and total affluent solids. In the third sampling, there was an increase in the total solids value from second to third point. This fact can be presupposed by the results of nitrogen and phosphorus analysis, which pointed an increasing from the second to third point, as these substances are in the form of suspended or dissolved solids. An average efficiency of $69.1 \%$ was observed for total solids removal in the system. The sump + filter set presented its best efficiency in the third sampling (82.3\%) and the flooded constructed in fourth sampling (38.6\%).

In the sampling at the first point, the COD increase from point two and three. This can be explained because of colour and turbidity, where the stabilization phase of the system caused a slowdown. Particles from the root zone substrate, if the chemical composition of the sand and gravel dust can increase COD values. 
BOD was removed during all the collected analyses, especially in first sampling, indicating a rapid stabilization of the system before the removal of organic loads.

The high values of organic and inorganic load pointed out in the first and second sampling the efficiency of the system in the treatment of tributaries with high rates of variation of COD and BOD. In addition, COD removal achieved an average efficiency of $86 \%$ and BOD $89 \%$ on the overall system. The septic tank and filter set obtained the best efficiency in sampling 1 (87.0\%) and the CW was more efficient in third sampling (84.0\%).

The result of the ammonia nitrogen concentration between the analysed points obtained significant variations, mainly regarding the removal efficiency in the system, as well as in the concentrations of the points two and three that did not obey the reduction logic, being observed in the first, second and third sampling (Figure 5). Valentim (2003) and Almeida (2007) explain the increase in ammonia nitrogen from point two to three through experiments that showed the same behaviour where plants cannot release enough oxygen for ammonia nitrogen oxidation. The hydrolysis of the particulate matter coming from the root-fixing substrate and retained in the $\mathrm{CW}$ generates the nitrogen and increase its concentration. It was also observed in relation to points two and three the elevation of $\mathrm{pH}$ and alkalinity as shown (Figure 6).

Figure 5 - Frequency of ammoniacal nitrogen values

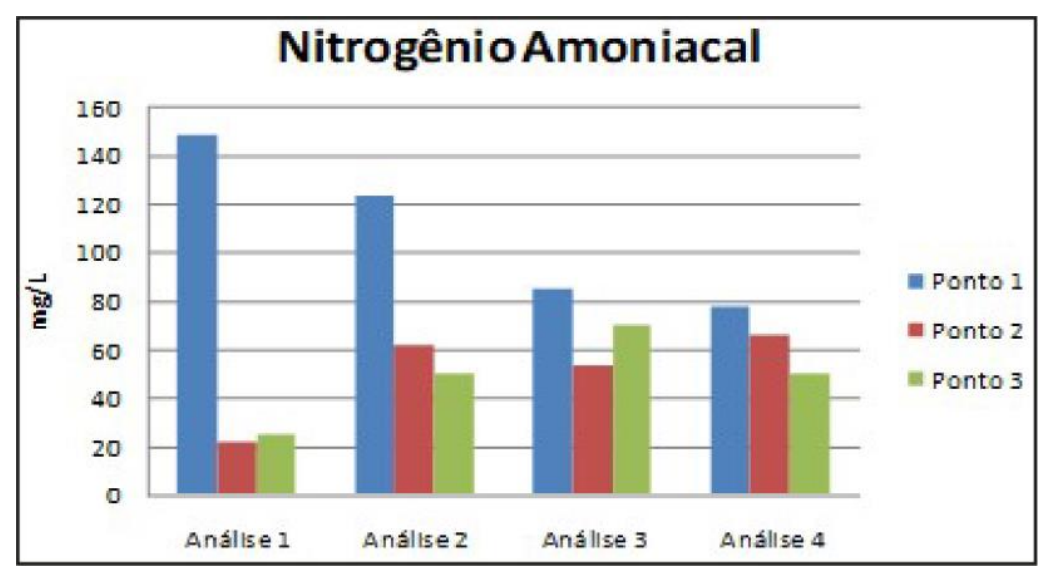

Source: Authors, 2021 
Figure 6 - Alkalinity and pH level in the samples

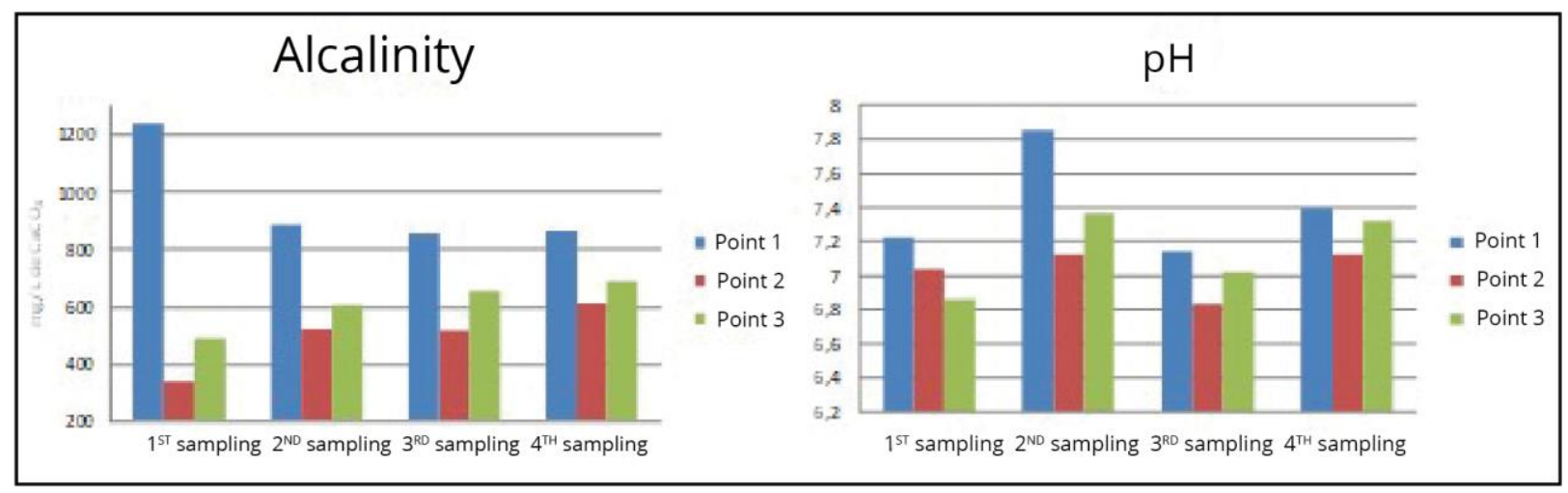

Source: Authors, 2021

For the conversion of $1 \mathrm{mg}$ of ammonia nitrogen to nitrite and nitrate, 4.57 mg of oxygen and $7.14 \mathrm{mg}$ of $\mathrm{CaCO}_{3}$ of alkalinity to bicarbonate are consumed (METCALF AND EDDY, 2005). Through the analysis can be observed the nitrification deficiency in the CW by the difficulty of the plants to release enough oxygen for such reactions, with no $\mathrm{H}^{+}$release or alkalinity consumption (Valentin 2003). Therefore, the removal of ammonia nitrogen by the root zone in the second, third and fourth sampling may also be largely due to the adsorption of this nutrient by the substrate biofilm (gravel and sand).

At the third sampling, the increase in concentration is explained by Valentim (2003) through the mobilization of nitrogen. The root system of plants that failed to sprout after transplantation and eventually decomposed, releasing nitrogen and other substances in the water present in the plant constructed flooded, if the constructed flooded system is still in the stabilization phase.

The hybrid system obtained $69.3 \%$ of efficiency removal, while the septic tank + filter set presented its best efficiency in third sampling (71.6\%) and the flooded constructed in fourth sampling (75.4\%). Total phosphorus showed a linear and gradual removal behaviour between points one, two and three (Figure 7). Adsorption and precipitation along with plant consumption are the main forms of phosphorus removal from natural systems (VALENTIN, 2003). 
Figure 7 - Total phosphorus in the samples

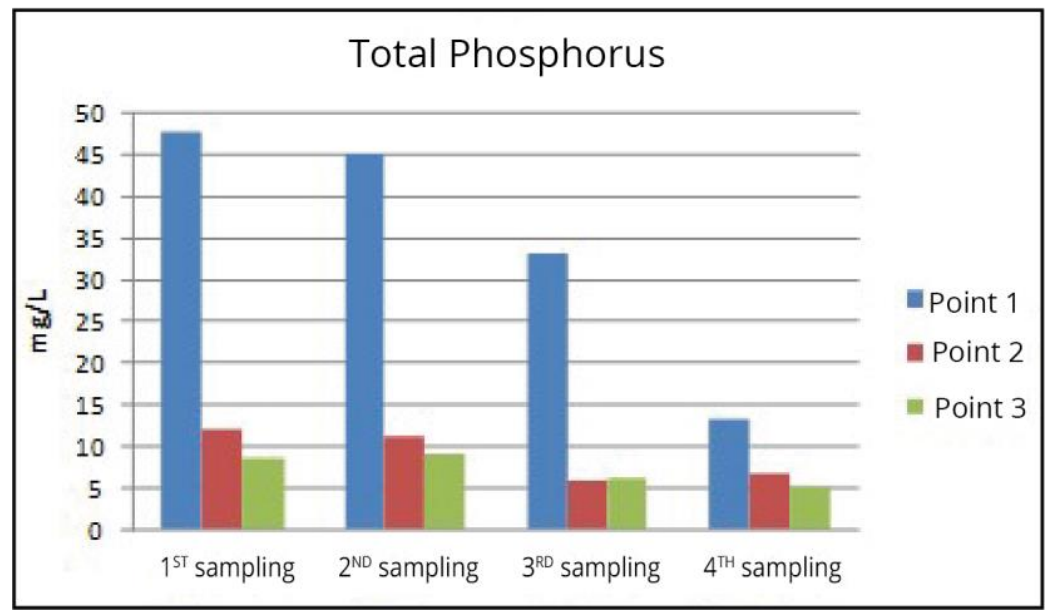

Source: Authors, 2021

The system obtained as average phosphorus removal efficiency $76.6 \%$, value lower than that found by Pitaluga (2011) of 93.9\%, operating only the CW of vertical flow with the marsh lily, showing the best yield of the plant when subjected to this type of flow. It is also worth addressing the issue of costs involved in project implementation. When comparing these costs involved in the construction of the system using the alternative material adopted with a standard masonry system, there is an approximate reduction of $67 \%$ in the final value of the entire work.

Replacing bricks and concrete with pellets in the septic tank and anaerobic filter and water tank in the CW, considerably reduced material costs. In addition, the use of these alternative materials required a professional workforce with basic knowledge of hydraulics to identify a suitable location for the gravity flow of the domestic effluent, allowing it to pass through all the wastewater treatment units.

In a system with five years of monitoring, the CW had a high efficiency of removal of organic pollutants and total suspended solids, and a lower efficiency of elimination of biogenic compounds, e.g., total nitrogen and total phosphorus. The removing of organic pollutants in the research period was $98.8 \%$ for $\mathrm{BOD}_{5}$ and $97.6 \%$ for COD (MARZEC et al., 2019).

To develop a region, managers (usually local governments) need to expand industrial production; however, these decisions inevitably lead to increased 
industrial waste such as wastewater, waste gas, and solid waste. The contamination carrying capacity of the natural environment, however, is limited; when pollution emissions exceed the carrying capacity upper bound, the ecosystem can be seriously damaged or destroyed (NI et al., 2018). Sanitation in most of the tropical areas, especially in small municipalities and rural areas, deals with much the same issues: high population growth, limited skilled human and financial resources, no sludge management solutions, as well as highly varying fluxes brought by tropical rain patterns (LOMBARD-NATUNE et al., 2018).

The system studied in the present research is a good option for rural communities. When considering sanitation in Brazilian poor communities, the problems linked with wastewater treatment are primarily related to the lack and/or stagnation of "cesspit", hole, well, or septic tank/ swallow-hole systems. Additionally, in most properties with septic tank/swallow-hole systems, the location (proximity to water bodies and groundwater) is not regulated, and the construction of these systems rarely follows specified guidelines. Several trends in the implementation of sustainable processes address the possibility of recovering materials, energy, and nutrients. This potential to recover resources is important in sustainable sanitation and particularly in wastewater treatment (LUTTERBECK et al., 2017).

\section{CONCLUSIONS}

The studied system presented satisfactorily average efficiency in some parameters, such as $90.8 \%$ in BOD removal and $87.9 \%$ in COD removal. Turbidity, apparent colour, and total solids obtained efficiencies of $69.3 \%, 89.4 \%$ and $69.1 \%$ respectively.

The average phosphorus removal efficiency was $76.6 \%$ and that of Nitrogen 46.3\%. The high efficiencies are largely due to the septic tank and anaerobic filter assembly, where considerable removal of some parameters from point one and 
two has been identified. The constructed flooded system was very efficient in removing BOD and COD, with efficiencies of up to $76.9 \%$ and $60.6 \%$, respectively.

\section{REFERENCES}

Almeida RA, Oliveira LFC, Kliemann HJ. Efficiency of plant species in sanitary sewage purification. Goiânia, Brazil; 2007.

Assefa R, Bai R, Leta S, Kloos H. Nitrogen removal in integrated anaerobic-aerobic sequencing batch reactors and constructed wetland system: a feld experimental study. Appl. Water Sci. 2019; 136: 1-11.

Ayaz SÇ, Aktas Ö, Akça L, Findik N. Effluent quality and reuse potential of domestic wastewater treated in a pilot-scale hybrid constructed wetland system. J. Environ. Manag. 2015; 156: 115120.

Ben W, Zhu B, Yuan X, Zhang Y, Yang M, Qiang Z. Occurrence, removal, and risk of organic micropollutants in wastewater treatment plants across China: Comparison of wastewater treatment processes. Water Research. 2018; 130: 38-46.

Chen D, Gu X, Zhu W, He S, Wu F, Huang J, Zhou W. Denitrification- and anammox-dominant simultaneous nitrification, anammox and denitrification (SNAD) process in subsurface flow constructed wetlands. Bioresource Technol. 2019; 271: 298-305.

Cruz LM, Stefanutti R, Coraucci Filho B, Tonetti A.L. Coconut shells as filling material for anaerobic filters. Springer Plus. 2013; 2: 655.

Diaz-Elsayed N, Xu X, Balaguer-Barbosa M, Zhang Q. An evaluation of the sustainability of onsite wastewater treatment systems for nutrient management. Water Research. 2017; 121: 186-196.

Ding X, Y Xue, Zhao Y, Xiao W, Liu Y, Liu J. Effects of different covering systems and carbon nitrogen ratios on nitrogen removal in surface flow constructed wetlands. J. Clean. Produc. 2018; 172: 541-551.

Guo C, Cui Y, Shi Y, Luo Y, Liu F, Wan D, Ma Z. Improved test to determine design parameters for optimization of free surface flow constructed wetlands. Biores. Technol. 2019; 280: 199-212.

Ijaz A, Shabir G, Khan QM, Afzal M. Enhanced remediation of sewage effluent by endophyteassisted floating treatment wetlands. Ecol Eng. 2015; 84: 58-66.

Jóźwiakowsk K, Marzec M, Kowalczyk-Juśko A., Gizińska-Górna M, Pytka-Woszczyło A, Malik A, Listosz A, Gajewska M. 25 years of research and experiences about the application of constructed wetlands in southeastern Poland. Ecological Engin. 2019; 127: 440-453. 
Kaliakatsos A, Kalogerakis N, Manios T, Venieri D. Efficiency of two constructed wetland systems for wastewater treatment: removal of bacterial indicators and enteric viruses. Journ. of Chem. Techno. and Biotechnol. 2019; 94: 7.

Kümmerer K, Dionysios DD, Olsson O, Fatta-Kassinos D. A path to clean water. Science. 2018; 361 (6399): 222-224.

Lombard-Latune R, Pelus L, Fina N, L'Etang F, Le Guennec B, Molle P. Resilience and reliability of compact vertical-flow treatment wetlands designed for tropical climates. Sci. of the Tot. Environ. 2018; 642: 208-215.

Lutterbeck CA, Kist LT, Lopez DR, Zerwes FV, Machado EL. Life cycle assessment of integrated wastewater treatment systems with constructed wetlands in rural areas. J. Clean. Product. 2017; 148: 527-536.

Marzec M, Gizińska-Górnaa M, Jóźwiakowskia K, Pytka-Woszczyłoa A, Kowalczyk-Juśkoa A, Gajewskab M. The efficiency and reliability of pollutant removal in a hybrid constructed wetland with giant miscanthus and Jerusalem artichoke in Poland. Ecolog. Engin. 2019; 127: 23-35.

Metcalf L. and Eddy H. Wastewater Engineering: Treatment and Reuse. New York, United States; 2005.

Mota FSB and Sperling MV. Sanitary sewage nutrients: use and removal. Rio de Janeiro, Brazil; 2009.

Peng L, Ni BJ, Erler D, Ye L, Yuan ZG. The effect of dissolved oxygen on N2O production by ammonia-oxidizing bacteria in an enriched nitrifying sludge. Water Res. 2014; 66: 12-21.

Pitaluga DPS. Evaluation of different substrates in sanitary sewage treatment by root zone. Goiânia, Brazil; 2011.

Sezerino PH, Philippi LS, Bento AP, Decezaro ST. Application of constructed wetland in wastewater treatment: use of filters planted with macrophytes. Florianópolis, Brazil; 2004.

Shingare RP, Nanekar SV, Thawale PR, Karthik R, Juwarkar AA. Comparative study on removal of enteric pathogens from domestic wastewater using Typha latifolia and Cyperus rotundus along with different substrates. Internat. J. Phytoremediation. 2017; 19: 899-908.

Svensson $\mathrm{H}$, Ekstam B, Marques M, Hogland W. Removal of organic pollutants from oak leachate in pilot scale wetland systems: How efficient are aeration and vegetation treatments? Water Res. 2015; 84: 120-126.

Trata Brasil. Wastewater: collection. Available in: http://www.tratabrasil.org.br/saneamento/principais-estatisticas/no-brasil/esgoto. Accessed on Mar. 16, 2021, 2019. 
Valentim MA. Performance of cultivated sewage treatment beds contributions to design and operation. Campinas, Brazil; 2003.

Xu X, Mills G, Lindell A, Peck E, Korotasz A, Burgess E. The performance of a free surface and metal-removing constructed wetland: How a young wetland becomes mature. Ecolog. Engin. 2019; 133: 32-38.

Wu H, Zhang J, Ngo HH, Guo W, Hu Z, Liang S, Fan J, Liu H. A review on the sustainability of constructed wetlands for wastewater treatment: Design and operation. Biores. Technol. 2015; 175: 594-601.

Wu HL, Wang XZ, He XJ, Zhang SB, Liang RB, Shen J. Effects of root exudates on denitrifier gene abundance, community structure and activity in a micro-polluted constructed wetland. Sci Total Environ. 2017; 598: 697-703.

Wu S, Lyu T, Zhao Y, Vymazal J, Arias CA, Brix H. Rethinking Intensification of Constructed Wetlands as a Green EcoTechnology for Wastewater Treatment. Environ. Sci. and Techno. 2018; 52: 1693-1694. 


\section{Authorship contributions}

\section{1 - Brennic Menezes Amaral:}

Graduated in Environmental and Sanitary Engineering

https://orcid.org/0000-0003-1021-4689•brennic96@gmail.com

Contribuição: Data Curation

\section{2 - Douglas Pires Alcântara:}

Graduated in Environmental and Sanitary Engineering

https://orcid.org/0000-0002-8380-9053・dpallcantara@gmail.com

Contribuição: Data Curation

\section{3 - Eva de Melo Ferreira}

Ph.D. in Environmental Science

https://orcid.org/0000-0002-1115-8976•emferreira.sci@gmail.com

Contribuição: Writing - review \& editing

\section{4 - Karla Alcione da Silva Cruvinel}

Ph.D. in Environmental Sciences

https://orcid.org/0000-0002-5110-565X•karlaalcione.ufg@gmail.com

Contribuição: Supervision

\section{How to quote this article}

AMARAL, B. M.; ALCÂNTARA, D.P.; FERREIRA, E. M.; CRUVINEL, K.A.S. Efficiency of pollutant removal in a hybrid constructed wetland with Hedychiumcoronarium J. König: a sustainable alternative for poor communities. Revista Monografias Ambientais, Santa Maria, v. 20, e6, 2021. DOI 10.5902/2236130866092. Disponível em: https://doi.org/10.5902/2236130866092. Acesso em: dia mês abreviado. ano. 